\title{
Counseling on homes and healthy lifestyles for Baduta Mothers in the stunting locus area
}

\section{Penyuluhan tentang rumah dan perilaku sehat pada Ibu Baduta di daerah lokus stunting}

\author{
Kholis Ernawati, Yusnita Yusnita, Fathul Jannah, Melsya Halim Utami, Annisa Rahmatia, \\ Chorunnisa Yaumal Akhir, Fitria Rizki
}

Fakultas Kedokteran, Universitas YARSI

Jl. Letjen Suprapto No. Kav.13, Daerah Khusus Ibukota Jakarta, 10510, Indonesia

\section{ARTICLE INFO: \\ Received: 2021-08-20 \\ Revised: 2021-10-16 \\ Accepted: 2021-12-21 \\ Keywords: \\ Education, Home environment, Occupant behaviour, Stunting}

\begin{abstract}
Home and the residential environment are one of the risk factors for stunting. The level of knowledge determines residents' behavior, and knowledge is influenced by the exposure to information that a person receives. The purpose of community service activities is counseling about healthy homes and healthy behavior to Baduta mothers (children under two years) in the stunting locus, Langensari village, Pandeglang district. Extension activities were carried out on September 20, 2019, in Langensari village, Saketi District, Pandeglang Regency. Before the activity was carried out, the team carried out advocacy and licensing at the Saketi District Health Center and the Langensari Village Head. The method used in this activity is advocacy and socialization of activities and activities using extension media using posters and brochures. The target of the counseling is the Baduta mother. Participants will be assessed whether there is increased knowledge about healthy homes and healthy behavior before and after counseling (pre-post-test). The result of the educational activity was that the extension participants consisted of 39 Baduta mothers. The difference in the mean score of the pre-post-test was 0.821, and the extension activities could increase the participants' knowledge before and after counseling $(p=0.018)$.
\end{abstract}

(C) 2022 Abdimas: Jurnal Pengabdian Masyarakat Universitas Merdeka Malang This is an open access article distributed under the CC BY-SA 4.0 license (https://creativecommons.org/licenses/by-sa/4.0/)

How to cite: Ernawati, K., Yusnita, Y., Jannah, F., Utami, M. H., Rahmatia, A., Akhir, C. Y., \& Rizki, F. (2022). Counseling on homes and healthy lifestyles for Baduta Mothers in the stunting locus area. Abdimas: Jurnal Pengabdian Masyarakat Universitas Merdeka Malang, 7(1), 178-186. https://doi.org/10.26905/abdimas.v7i1.6259

\section{PENDAHULUAN}

Balita yang memiliki panjang atau tinggi badan yang kurang jika dibandingkan dengan umurnya disebut sebagai kondisi stunting. Pengukuran panjang atau tinggi badan tersebut lebih dari -2 SD median yang merupakan ukuran standar pertumbuhan anak balita sesuai panduan dari WHO (Kemenkes RI, 2018; UNICEF, 2013). Stunting juga dapat menjadi indikator status kesehatan anak dengan kondisi kekurangan gizi kronis dan hal tersebut menggambarkan status gizi anak pada masa sebelumnya yang dipengaruhi oleh ekonomi, sosial, dan lingkungan keluarga anak tersebut (UNICEF, 2013). 
WHO pada tahun 2018 melaporkan bahwa angka kejadian stunting di Indonesia termasuk urutan ketiga di Asia Tenggara. Potensi stunting balita di Indonesia masih mengalami peningkatan. Hal ini dapat dilihat data tahun 2016, prevalensi balita sangat pendek dan pendek sebesar 8,5\% dan 19\%. Kemudian pada tahun 2017 terjadi peningkatan yaitu 9,8\% dan 19,8\% dengan prevalensi tertinggi adalah provinsi Nusa Tenggara Timur dan provinsi dengan prevalensi terendah adalah Bali (Kementerian Kesehatan RI, 2018).

Menurut Kemenkes 2018, Provinsi Banten mengalami penurunan kasus stunting pada tahun 2019 sebesar 24,1\% dari sebelumnya 29,6\% pada tahun 2017. Kabupaten Pandeglang pada tahun 2013 memiliki prevalensi stunting sebesar 38,57\% (46.775 jiwa) sedangkan pada tahun 2019 prevalensi stunting sebesar 34,01\%, sehingga Kabupaten Pandeglang menjadi satu-satunya kabupaten di Provinsi Banten yang termasuk 100 kabupaten di seluruh Indonesia dengan prioritas masalah stunting. Penduduk Pandeglang tahun 2016 sebesar 1.199 jiwa, sedangkan prevalensi stunting pada tahun 2013 mencapai 38,57\%. Sementara jumlah balita stunting pada tahun 2013 sebesar 46.775 jiwa. Terdapat 10 desa di Kabupaten Pandeglang yang menjadi daerah lokus sasaran program penanganan stunting yaitu Desa Tegal Lengok, Keroncong, Pakuluran, Pasirkarang, Kadumaneuh, Banyumadu, Kadugadung, Koncang, Langensari, dan Pasirdurung (Tim Nasional Percepatan Penanggulangan Kemiskinan, 2018)

Stunting pada anak disebabkan oleh banyak faktor, di antaranya seperti asupan gizi balita yang kurang sehingga dapat mempengaruhi tumbuh kembang dan tumbuh kejar (Kementerian PPN, 2018). Menurut penelitian yang dilakukan oleh Lawaceng \& Rahayu (2020), beberapa faktor penyebab tingginya prevalensi stunting di Kabupaten Pandeglang adalah masalah pola asuh, asupan makanan, pelayanan kesehatan, serta akses ke air bersih dan sanitasi (Lawaceng \& Rahayu, 2020). Sanitasi dan keamanan pangan yang buruk menjadi faktor tidak langsung kejadian stunting yang dapat meningkatkan risiko terjadinya penyakit infeksi, misalnya diare dan kecacingan yang menyebabkan terjadinya gangguan penyerapan nutrisi. Jika hal tersebut berlangsung terus menerus dalam jangka waktu panjang serta tidak dilakukan intervensi asupan gizi yang cukup maka berpotensi terjadi stunting (Kemenkes RI, 2018). Oleh karenanya diperlukan peran serta keluarga dalam memenuhi kebutuhan gizi anak dengan memanfaatkan pekarangan sebagai sumber gizi keluarga dan perbaikan sanitasi lingkungan (Kusumawati \& Rahardjo, 2013).

Pemerintah Indonesia melakukan program intervensi gizi dalam rangka menyelesaikan permasalahan stunting. Intervensi gizi meliputi dua hal yaitu intervensi gizi spesifik dan intervensi gizi sensitif. Selain itu juga menyediakan dan memastikan akses air bersih dan sanitasi yang memenuhi syarat kesehatan melalui program PAMSIMAS (Penyediaan Air Bersih dan Sanitasi berbasis Masyarakat), menyediakan jaminan kesehatan nasional (JKN) dan jaminan persalinan universal (JAMPERSAL), pendidikan kesehatan tentang pengasuhan balita, gizi masyarakat yang dilakukan oleh puskesmas, posyandu, dan lain-lain (Tim Nasional Percepatan Penanggulangan Kemiskinan, 2017)

Diketahui juga bahwa faktor lain seperti kondisi lingkungan fisik rumah yang meliputi jenis lantai dan dinding rumah juga berhubungan dengan kejadian stunting balita meskipun hasil penelitiannya masih terbatas. Sumber polutan domestik yang meliputi jenis bahan bakar untuk memasak dan paparan asap rokok juga memiliki hubungan signifikan dengan stunting meskipun hanya terdapat pada beberapa penelitian. Jamban yang tidak memenuhi syarat berpotensi memicu timbulnya penyakit infeksi yang dapat menganggu penyerapan nutrisi pada proses pencernaan (Kemenkes Rl, 2018).

Kondisi rumah sehat dapat tercipta dengan Perilaku Hidup Bersih dan Sehat (PHBS) yang dilakukan oleh anggota keluarga antara lain dengan membuat jamban yang memenuhi syarat (leher angsa dengan septictank dan terjaga kebersihannya), anggota rumah tangga tidak ada yang merokok di dalam rumah, 
ABDIMAS: Jurnal Pengabdian Masyarakat Universitas Merdeka Malang

Volume 7, No 1, February 2022: 178-186

mencuci tangan menggunakan sabun dan air mengalir pada waktu sebelum makan dan sesudah BAB, serta melakukan PSN (Pemberantasan Sarang Nyamuk) minimal seminggu sekali dengan gerakan 3M (Menguras, Menutup, dan Mengubur) (Rahmah, 2015). Perilaku merokok sangat terkait dengan kejadian stunting. Menurut penelitian Utami et al. (2013), menyatakan bahwa proporsi kejadian anak stunting pada kelompok pajanan asap rokok dengan waktu lebih dari 10 tahun sebesar 78,4\%. Angka tersebut lebih tinggi dari pada kejadian stunting pada anak dengan lama pajanan merokok kurang dari 10 tahun yaitu sebesar 8,1\% (Utami et al., 2013).

Perilaku kesehatan adalah suatu respon seseorang terhadap stimulasi yang berkaitan dengan sakit dan penyakit, sistem pelayanan kesehatan, makanan, serta lingkungan. Perilaku merupakan salah satu faktor yang mempengaruhi derajat kesehatan manusia (Adliyani, 2015). Penyuluhan yang merupakan kegiatan edukasi dapat meningkatkan pengetahuan dan selanjutnya dapat mempengaruhi perilaku seseorang. Menciptakan perilaku keluarga yang sehat dan rumah sehat sebagai salah satu upaya preventif terhadap kejadian stunting pada baduta.

Berdasarkan latar belakang di atas maka tujuan dari kegiatan ini adalah mengadakan penyuluhan tentang rumah sehat dan perilaku sehat pada ibu yang memiliki anak balita berusia dua tahun (BADUTA) di Desa Langensari, Kabupaten Pandeglang.

\section{METODE}

Kegiatan penyuluhan tentang rumah sehat dan perilaku sehat pada keluarga dilaksanakan pada tanggal 20 September 2019 di Desa Langensari, Kecamatan Saketi, Kabupaten Pandeglang. Desa Langensari adalah salah satu desa dari sepuluh desa yang menjadi lokus penanganan stunting di Kabupaten Pandeglang. Kabupaten Pandeglang adalah satu-satunya kabupaten di Provinsi Banten yang termasuk 100 kabupaten di seluruh Indonesia dengan prioritas penanganan masalah stunting.

Sebelum kegiatan dilakukan, tim melakukan advokasi dan perizinan ke Puskesmas Saketi dan Kepala Desa Langensari. Peserta kegiatan pengabdian masyarakat adalah 39 orang ibu yang memiliki anak bawah usia dua tahun (baduta). Metode yang dilakukan pada kegiatan ini adalah berupa penyuluhan, dengan alat bantu media penyuluhan menggunakan poster yang sudah mendapatkan HKI (No. EC00202000026) dan brosur (Gambar 1 dan Gambar 2). Peserta dinilai apakah terdapat peningkatan pengetahuan tentang rumah sehat dan perilaku sehat sebelum dan sesudah penyuluhan (pre-test dan post-test) menggunakan kuesioner dengan jumlah pertanyaan 17 item tentang rumah yang meliputi aspek rumah sehat, langit-langit, dinding, lantai, kamar tidur, jendela, ventilasi pencahayaan, sumber air, jamban, dan pembuangan air limbah. Sedangkan pertanyaan tentang perilaku penghuni rumah meliputi membuka jendela, pembuangan tinja, pembuangan sampah, perilaku merokok, perilaku penggunaan insektisida, dan perilaku penggunaan wadah plastik untuk menyimpan makanan panas.

Sebelum kegiatan penyuluhan, juga dilakukan pengukuran tinggi badan pada anak responden yang berumur bawah dua tahun (baduta) untuk mengetahui status stunting atau tidak stunting dengan menggunakan indikator gizi TB/U sama dengan atau kurang dari minus dua standar deviasi (-2 SD) di bawah rata-rata standar atau keadaan dimana tubuh anak lebih pendek dibandingkan dengan anakanak lain seumurnya ( Kemenkes RI, 2018; UNICEF, 2013).

Data yang diperoleh kemudian diolah dengan menggunakan aplikasi SPSS versi 23 menggunakan uji normalitas Shapiro Wilk dan dilanjutkan uji statistik dengan uji Wilcoxon untuk melihat perbedaan tingkat pengetahuan peserta sebelum dan sesudah penyuluhan. 

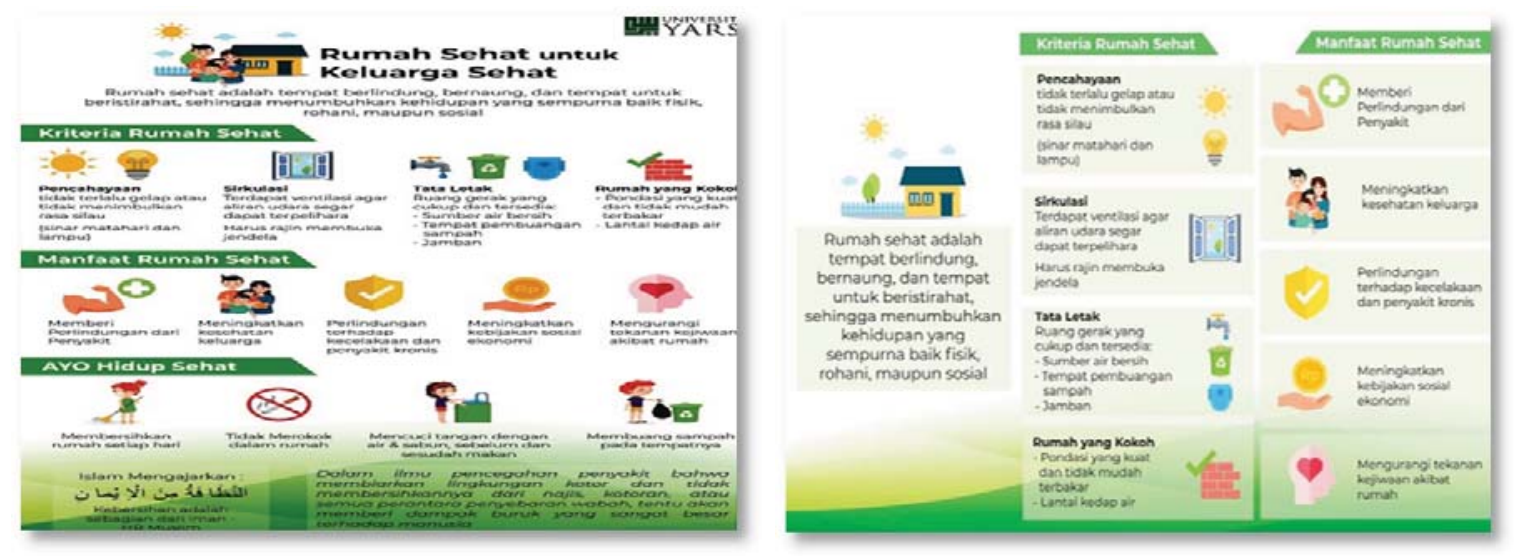

Gambar 1. Media edukasi 1 (poster)

Gambar 2. Media edukasi 2 (brosur)

\section{HASIL DAN PEMBAHASAN}

Sebelum kegiatan penyuluhan dilakukan kegiatan advokasi, sosialiasi, dan perizinan kepada Puskesmas Kecamatan Saketi dan Kepala Desa Langensari (Gambar 3). Beberapa kesepakatan dari hasil kegiatan yaitu tentang teknis pelaksanaan kegiatan yang meliputi tanggal, lokasi, peserta, dan sususan acara. Kegiatan pengabdian masyarakat dilaksanakan pada tanggal 20 September 2019 di Balai Desa Langensari (Gambar 4 dan 5). Sasaran kegiatan adalah ibu yang memiliki anak bawah usia dua tahun (baduta) yang berpotensi stunting dan akses mudah dari rumahnya untuk menuju balai desa. Kegiatan akan dibantu oleh bidan desa puskesmas. Media yang digunakan dalam penyuluhan yaitu poster dan brosur.

Kegiatan penyuluhan ini dimulai dengan pembukaan oleh Kepala Desa Langensari dan perwakilan dari Puskesmas Saketi dilanjutkan pengisian pre-test oleh peserta selama 10-15 menit, kemudian dilanjutkan dengan sesi penyuluhan dan juga tanya jawab, pengisian post-test selama 10-15 menit dan diikuti dengan penutupan.
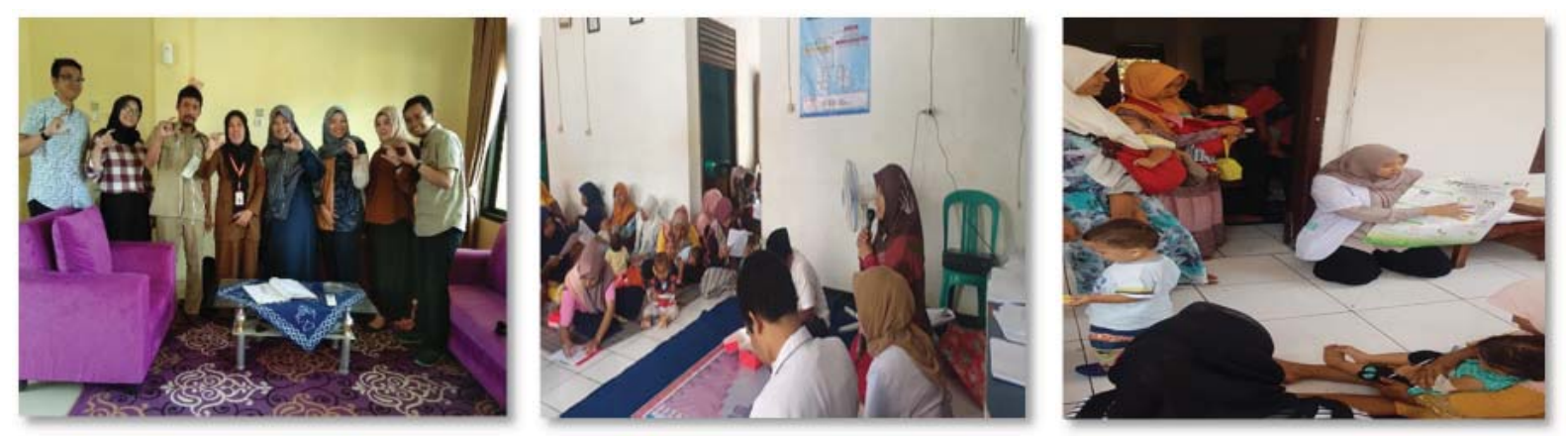

Gambar 3. Advokasi, sosialisasi dan perizinan

Gambar 4. Pelaksanaan kegiatan (1)

Gambar 5. Pelaksanaan kegiatan (2) 
ABDIMAS: Jurnal Pengabdian Masyarakat Universitas Merdeka Malang Volume 7, No 1, February 2022: 178-186

Tabel 1. Karakteristik responden (ibu) dan bayi bawah dua tahun (baduta)

\begin{tabular}{lc}
\hline Karakteristik & Jumlah \\
\hline Ibu & \\
Usia (tahun) & 15 \\
$15-25$ & 16 \\
$26-35$ & 8 \\
$36-45$ & 39 \\
Total & \\
Pendidikan & 3 \\
Tidak Bersekolah & 5 \\
SD & 14 \\
SMP & 17 \\
SMA & 39 \\
Total & \\
Baduta & \\
Jenis Kelamin & \\
Laki-Laki & 20 \\
Perempuan & 19 \\
Total & 39 \\
Status Stunting Baduta & \\
Stunting & \\
Tidak Stunting & 21 \\
Total & \\
\hline
\end{tabular}

Berdasarkan karakteristik responden pada Tabel 1, didapatkan paling banyak ibu berusia antara 2635 tahun yaitu 16 orang dengan tingkat pendidikan terbanyak yaitu SMA sejumlah 17 orang. Sedangkan untuk baduta (anak responden) paling banyak adalah jenis kelamin laki-laki sebanyak 20 orang dan 18 anak baduta termasuk stunting.

Pada Tabel 2 jawaban pada pre-test dan post-test dibagi menjadi benar dan salah. Tiap pertanyaan memberikan gambar pengetahuan masing-masing aspek. Secara garis besar dari 17 pertanyaan yang diajukan pada responden, 11 pertanyaan ditujukan untuk melihat pengetahuan mengenai rumah sehat sedangkan 6 pertanyaan lainnya (nomor 12-17) bertujuan untuk melihat pengetahuan mengenai perilaku penghuni rumah sehat.

Pada jawaban pre-test dan post-test mengenai pertanyaan pada soal nomor 6 dan 8 mengenai aspek jendela dan pencahayaan menunjukkan nilai yang tetap. Kenaikan nilai terlihat pada pertanyaan soal nomor 1,2,3,4,7,10,11,13,14,16,17 mengenai aspek rumah sehat, langit-langit, dinding, lantai, ventilasi, jamban, pembuangan air limbah, pembuangan tinja, pembuangan sampah, perilaku penggunaan insektisida pengusir nyamuk, dan perilaku penggunaan wadah plastik. Sedangkan, untuk nilai yang turun terdapat pada pertanyaan soal nomor 5, 9 dan 12 mengenai aspek kamar tidur, sumber air, dan perilaku membuka jendela.

Sebelum dilakukan uji T berpasangan, dilakukan uji normalitas data dengan menggunakan Shapiro-wilk (tabel 3) dengan hasil nilai p pre-test yaitu 0,64 dan post-test yaitu 0,127, yang artinya sebaran data normal karena nilai $p>0,05$ sehingga dapat dilakukan uji t berpasangan. 
Counseling on homes and healthy lifestyles for Baduta Mothers in the stunting locus area

Kholis Ernawati, Yusnita Yusnita, Fathul Jannah, Melsya Halim Utami, Annisa Rahmatia, Chorunnisa Yaumal Akhir, Fitria Rizki

Tabel 2. Jawaban pre dan post test per-pertanyaan

\begin{tabular}{|c|c|c|c|c|}
\hline \multirow[t]{2}{*}{ Pertanyaan } & \multicolumn{2}{|c|}{ Jawaban Pretest } & \multicolumn{2}{|c|}{ Jawaban Posttest } \\
\hline & Benar & Salah & Benar & Salah \\
\hline \multicolumn{5}{|c|}{ Rumah Sehat } \\
\hline \multirow[t]{2}{*}{ Aspek Rumah Sehat } & 25 & 14 & 28 & 11 \\
\hline & $(64,1 \%)$ & $(35,9 \%)$ & $(71,8 \%)$ & $(28,2 \%)$ \\
\hline \multirow[t]{2}{*}{ Langit-Langit } & 36 & 3 & 37 & 2 \\
\hline & $(92,3 \%)$ & $(7,7 \%)$ & $(94,9 \%)$ & $(5,1 \%)$ \\
\hline \multirow[t]{2}{*}{ Dinding } & 34 & 5 & 37 & 2 \\
\hline & $(87,2 \%)$ & $(12,8 \%)$ & $(94,9 \%)$ & $(5,1 \%)$ \\
\hline \multirow[t]{2}{*}{ Lantai } & 33 & 6 & 36 & 3 \\
\hline & $(84,6 \%)$ & $(11,4 \%)$ & $(92,3 \%)$ & $(7,7 \%)$ \\
\hline \multirow[t]{2}{*}{ Kamar Tidur } & 17 & 22 & 12 & 27 \\
\hline & $(43,6 \%)$ & $(56,4 \%)$ & $(30,8 \%)$ & $(69,2 \%)$ \\
\hline \multirow[t]{2}{*}{ Jendela } & 38 & 1 & 38 & 1 \\
\hline & $(97,4 \%)$ & $(2,6 \%)$ & $(97,4 \%)$ & $(2,6 \%)$ \\
\hline \multirow[t]{2}{*}{ Ventilasi } & 15 & 24 & 29 & 10 \\
\hline & $(38,5 \%)$ & $(61,5 \%)$ & $(74,4 \%)$ & $(25,6 \%)$ \\
\hline \multirow[t]{2}{*}{ Pencahayaan } & 37 & 2 & 37 & 2 \\
\hline & $(94,9 \%)$ & $(5,1 \%)$ & $(94,9 \%)$ & $(5,1 \%)$ \\
\hline \multirow[t]{2}{*}{ Sumber Air } & 16 & 23 & 9 & 30 \\
\hline & $(41 \%)$ & (59\%) & $(23,1 \%)$ & $(76,9 \%)$ \\
\hline \multirow[t]{2}{*}{ Jamban } & 27 & 12 & 32 & 7 \\
\hline & $(69,2 \%)$ & $(30,8 \%)$ & $(82,1 \%)$ & $(17,9 \%)$ \\
\hline \multirow[t]{2}{*}{ Pembuangan Air Limbah } & 15 & 24 & 18 & 21 \\
\hline & $(38,5 \%)$ & $(61,5 \%)$ & $(46,2 \%)$ & $(53,8 \%)$ \\
\hline \multicolumn{5}{|c|}{ Perilaku Penghuni Rumah Sehat } \\
\hline \multirow[t]{2}{*}{ Membuka Jendela } & 34 & 5 & 32 & 7 \\
\hline & $(87,2 \%)$ & $(12,8 \%)$ & $(82,1 \%)$ & $(17,9 \%)$ \\
\hline \multirow[t]{2}{*}{ Pembuangan Tinja } & 30 & 9 & 32 & 7 \\
\hline & $(76,9 \%)$ & $(23,1 \%)$ & $(82,1 \%)$ & $(17,9 \%)$ \\
\hline Pembuangan Sampah & $\begin{array}{r}20 \\
(51,3 \%)\end{array}$ & $\begin{array}{r}19 \\
(48,7 \%)\end{array}$ & $\begin{array}{r}33 \\
(84,6 \%)\end{array}$ & $6(15,4 \%)$ \\
\hline \multirow[t]{2}{*}{ Perilaku Merokok } & 37 & 2 & 36 & 3 \\
\hline & $(94,9 \%)$ & $(5,1 \%)$ & $(92,3 \%)$ & $(7,7 \%)$ \\
\hline Perilaku Penggunaan & 28 & 11 & 30 & 9 \\
\hline Insektisida Pengusir Nyamuk & $(71,8 \%)$ & $(28,2 \%)$ & $(76,9 \%)$ & $(23,1 \%)$ \\
\hline \multirow{2}{*}{$\begin{array}{l}\text { Perilaku Penggunaan Wadah } \\
\text { Plastik }\end{array}$} & 32 & 7 & 33 & 6 \\
\hline & $(82,1 \%)$ & $(17,9 \%)$ & $(84,6 \%)$ & $(15,4 \%)$ \\
\hline \multirow[t]{2}{*}{ Nilai Rata-rata } & 27,9 & 11,1 & 29,9 & 9,1 \\
\hline & $(71,5 \%)$ & $(28,5 \%)$ & $(76,7 \%)$ & $(23,3 \%)$ \\
\hline
\end{tabular}


ABDIMAS: Jurnal Pengabdian Masyarakat Universitas Merdeka Malang

Volume 7, No 1, February 2022: 178-186

Tabel 3. Hasil uji normalitas data variabel total nilai pre-test dan post-test dengan Shapiro-Wilk

\begin{tabular}{cc}
\hline Variabel & Nilai $\mathbf{p}$ \\
\hline Pre-test & 0,64 \\
Post-test & 0,127 \\
\hline
\end{tabular}

Tabel 4. Hasil uji T berpasangan pada variabel nilai pre-test dan post-test

\begin{tabular}{lccc}
\hline Variabel & Mean & T & Nilai $\mathbf{P}$ \\
\hline Pretest-Posttest & 0,821 & $-2,484$ & 0,018 \\
\hline
\end{tabular}

Pada uji t berpasangan (Tabel 4) didapatkan hasil rata-rata pre-test dan post-test adalah 0,821. Nilai $T$ hasil yang didapat adalah $-2,484$. Sedangkan nilai $P=0,018$. Hal ini menunjukkan bahwa penyuluhan tentang rumah sehat dan perilaku penghuni rumah sehat memberikan perbaikan pengetahuan pada 39 responden yang hadir.

Hasil dari kegiatan penyuluhan menunjukkan bahwa nilai hasil post-test lebih tinggi dibandingkan nilai pre-test dengan nilai rata-rata jawaban responden benar pada pre-test sebesar $27,9 \%$ dan pada post-test sebesar 29,9\%. Jawaban benar pada setiap soal juga sebagian besar naik. Dari 17 soal kuesioner terjadi peningkatan nilai pada soal kuesioner sebanyak 11 nomor, sedangkan yang jawabannya tetap sebanyak dua nomor dan nilai yang turun sebanyak tiga nomor soal.

Kegiatan penyuluhan merupakan bagian dari pendidikan kesehatan dengan tujuan untuk menyampaikan pesan dan menanamkan keyakinan sehingga masyarakat menjadi sadar, tahu, dan mengerti, serta berikutnya mau dan bisa melakukan suatu anjuran yang ada hubungannya dengan kesehatan (Notoatmodjo, 2012). Hasil penelitian menunjukkan bahwa pesan yang disampaikan yaitu aspek rumah sehat dan perilaku sehat yang dapat menjadi penyebab stunting pada balita dapat dipahami oleh ibu-ibu peserta penyuluhan dan dapat meningkatkan pengetahuannya.

Metode yang dilakukan pada kegiatan ini berupa penyuluhan, dengan alat bantu media menggunakan poster dan brosur. Salah satu faktor yang dapat mempengaruhi peningkatan pengetahuan adalah media massa atau informasi (Budiman \& Riyanto, 2013). Warna poster dan brosur yang digunakan yaitu hijau, dengan latar belakang putih dan kuning sehingga poster terlihat cerah dan diharapkan dapat menarik perhatian mata, sehingga responden melihat dan membaca poster serta brosur yang digunakan sebagai media dalam kegiatan penyuluhan. Penggunaan warna pada poster dan brosur tersebut sesuai dengan hasil penelitian yang menunjukkan bahwa warna dasar paling disukai untuk digunakan pada sebuah media adalah warna putih, hijau, atau merah (Huddle, 2000).

Pada kegiatan penyuluhan ini, materi rumah sehat dan perilaku sehat dijadikan materi penyuluhan karena kedua materi tersebut termasuk faktor risiko terjadinya stunting sebagaimana hasil beberapa penelitian lain. Balita yang tumbuh pada lingkungan rumah yang tidak memenuhi syarat kesehatan berisiko satu kali lebih besar akan mengalami status gizi buruk dibandingkan dengan anak balita yang hidup dalam lingkungan rumah yang sehat (Hidayat \& Fuada, 2011). Kondisi rumah yang tidak memenuhi syarat kesehatan, sanitasi lingkungan yang buruk, dan budaya yang tidak sehat merupakan faktor risiko terjadinya stunting pada anak-anak di Indonesia (Budiastutik \& Rahfiludin, 2019). Keluarga dengan saluran pembuangan air limbah yang buruk mempunyai peluang 2,250 kali mengalami stunting dibandingkan dengan keluarga yang pembuangan air limbah rumah tangganya baik (Soeracmad, 2019). Anak-anak kelompok usia 6-24 bulan yang tinggal di rumah dengan sarana sanitasi yang tidak memenuhi syarat akan berpeluang 31,875 kali mengalami stunting (Herawati et al., 2020). Perilaku higiene buruk yang diterapkan oleh keluarga berhubungan secara bermakna dengan terjadinya stunting pada balita berusia 12-59 bulan $(p=0.000)$ (Khairiyah \& Fayasari, 2020). 


\section{SIMPULAN DAN SARAN}

Penyuluhan terhadap 39 orang ibu baduta di Desa Langensari, Kecamatan Saketi, Kabupaten Pandeglang dengan media poster dan brosur berjalan baik dan hasilnya dapat meningkatkan pengetahuan pre-post-test tentang rumah sehat dan perilaku sehat dalam rangka pencegahan stunting $(p=0,018)$.

Keterbatasan pada kegiatan ini adalah waktu penyuluhan yang sempit dan tempat penyuluhan di kantor desa yang tidak begitu luas dibanding jumlah peserta yang hadir (ibu-ibu rumah tangga yang membawa anak-anak mereka yang masih balita) mempengaruhi kelancaran kegiatan dan kemungkinan berpengaruh terhadap hasil kegiatan. Oleh karenanya, tim pengabdi masyarakat berikutnya dapat melakukan kegiatan serupa dengan mempertimbangkan waktu yang lebih lama dan tempat penyuluhan yang lebih luas. Saran untuk peserta kegiatan penyuluhan yaitu lbu-ibu yang mempunyai Baduta diharapkan dapat mengaplikasikan informasi yang telah diperoleh dalam kehidupan sehari-hari dan dapat menyampaikan kepada anggota keluarga yang lain serta warga di sekitar tempat tinggal mereka.

\section{UCAPAN TERIMA KASIH}

Kegiatan pengabdian masyarakat terselenggara atas bantuan dan dukungan kampus Universitas YARSI yang memberikan dana hibah pengabdian masyarakat internal tahun 2018-2019. Terima kasih kepada seluruh staf Puskesmas Kecamatan Saketi dan Kepala Desa Langensari beserta perangkat desa lainnya dan ibu-ibu baduta yang telah banyak membantu kegiatan penyuluhan. Juga terima kasih kepada mahasiswa profesi kedokteran (Ajeng Halida, Arki Farros, Aryanata Ryan Kurniawan, Audrey Kumala, Laura Rahardini, M. Fikri Satria Kamal, Rifqi Akbar Hidayat) yang telah membantu kegiatan penyuluhan.

\section{DAFTAR PUSTAKA}

Adliyani, Z. O. N. (2015). Pengaruh perilaku individu terhadap hidup sehat. Jurnal Majority, 4(7), 109114.

Budiastutik, I., \& Rahfiludin, M.Z. (2019). Faktor risiko stunting pada anak di negara berkembang. Amerta Nutrition, 3(3), 122-129. http://dx.doi.org/10.20473/amnt.v3i3.2019.122-129

Budiman, B., \& Riyanto, A. (2013). Kapita selekta kuesioner: Pengetahuan dan sikap dalam penelitian kesehatan. Jakarta: Salemba Medika.

Herawati, H., Anwar, A., \& Setyowati, D. L. (2020). Hubungan sarana sanitasi, perilaku penghuni, dan kebiasaan cuci tangan pakai sabun (CTPS) oleh ibu dengan kejadian pendek (stunting) pada batita usia 6-24 bulan di wilayah kerja Puskesmas Harapan Baru, Samarinda. Jurnal Kesehatan Lingkungan Indonesia, 19(1), 7-15. https://doi.org/10.14710/jkli.19.1.7-15

Hidayat, T. S., \& Fuada, N. (2011). Hubungan sanitasi lingkungan, morbiditas dan status gizi balita di Indonesia (relationship between environmental sanitation, morbidity and nutritional status of under-five children In Indonesia). Nutrition and Food Research, 34(2), 223482.

Huddle, P. A. (2000). How to present a paper or poster. Journal of Chemical Education, 77(9), 1152. https://doi.org/10.1021/ed077p1152

Kemenkes RI. (2018). Buletin stunting. Kementerian Kesehatan RI, 301(5), 1163-1178.

Kementerian Kesehatan RI. (2018). Buku saku pemantauan status gizi tahun 2017. Kementerian Kesehatan RI. 
ABDIMAS: Jurnal Pengabdian Masyarakat Universitas Merdeka Malang Volume 7, No 1, February 2022: 178-186

Kementerian PPN. (2018). Pedoman pelaksanaan intervensi penurunan stunting terintegrasi di kabupaten/kota. Kementerian Perencanaan dan Pembangunan Nasional.

Khairiyah, D., \& Fayasari, A. (2020). Perilaku higiene dan sanitasi meningkatkan risiko kejadian stunting balita usia 12-59 bulan di Banten. Ilmu Gizi Indonesia, 3(2), 123-134. https://doi.org/10.35842/ilgi.v3i2.137

Kusumawati, E., Rahardjo, S., \& Sari, H. P. (2015). Model pengendalian faktor risiko stunting pada anak bawah tiga tahun. Kesmas: Jurnal Kesehatan Masyarakat Nasional (National Public Health Journal), 9(3), 249-256. http://dx.doi.org/10.21109/kesmas.v9i3.572

Lawaceng, C., \& Rahayu, A. Y. S. (2020). Tantangan pencegahan stunting pada era adaptasi baru "New Normal" melalui pemberdayaan masyarakat di Kabupaten Pandeglang. Jurnal Kebijakan Kesehatan Indonesia: JKKI, 9(3), 136-146. https://doi.org/10.22146/jkki.57781

Notoatmodjo, S. (2012). Promosi kesehatan \& ilmu perilaku. Jakarta: Rineka Cipta.

Rahmah, U. D. M. N. (2015). Hubungan karakteristik kepala keluarga dengan rumah sehat di Desa Duwet Kecamatan Baki Kabupaten Sukoharjo. Doctoral Dissertation. Universitas Muhammadiyah Surakarta.

Soeracmad, Y. S. Y. (2019). Hubungan sanitasi lingkungan rumah tangga dengan kejadian stunting pada anak balita di Puskesmas Wonomulyo Kabupaten Polewali Mandar Tahun 2019. J-KESMAS: Jurnal Kesehatan Masyarakat, 5(2), 138-150. http://dx.doi.org/10.35329/jkesmas.v5i2.519

Tim Nasional Percepatan Penanggulangan Kemiskinan. (2017). 100 kabupaten/kota prioritas untuk intervensi anak kerdil (stunting). Jakarta: Tim Nasional Percepatan Penanggulangan Kemiskinan.

Tim Nasional Percepatan Penanggulangan Kemiskinan. (2018). 100 kabupaten/kota prioritas untuk intervensi anak kerdil (stunting). Jakarta: Tim Nasional Percepatan Penanggulangan Kemiskinan.

UNICEF. (2013). Improving child nutrition: The achievable imperative for global progress., Division of Communication. UNICEF.

Utami, R. P., Suhartono, S., Nurjazuli, N., Kartini, A., \& Rasipin, R. (2013). Faktor lingkungan dan perilaku yang berhubungan dengan kejadian stunting pada siswa SD di wilayah pertanian (Penelitian di Kecamatan Bulakamba Kabupaten Brebes). Jurnal Kesehatan Lingkungan Indonesia, 12(2), 127-131. https://doi.org/10.14710/jkli.12.2.127\%20-\%20131 